\title{
PENGETAHUAN ORANGTUA BERHUBUNGAN DENGAN KEJADIAN ISPA PADA BALITA DI PUSKESMAS KUMBE KOTA BIMA
}

\author{
Nurwahidah ${ }^{1}$, A. Haris ${ }^{2}$ \\ ${ }^{1}$ Jurusan Keperawatan/Poltekkes Kemenkes Mataram/Indonesia \\ ${ }^{2}$ Fakultas/ Jurusan, Universitas/ Institusi, Negara
}

\begin{abstract}
Abstrak
Saat ini ISPA masih menjadi masalah kesehatan dunia. Berdasarkan WHO (2007) ISPA adalah penyebab utama morbiditas dan mortalitas penyakit menular didunia. Hampir 4 juta orang meninggal akibat ISPA setiap tahun, 98\% nya disebabkan oleh infeksi saluran pernapasan bawah. Tingkat mortalitas sangat tinggi pada bayi,balita-balita dan orang lanjut usia, terutama di Negara-negara dengan pendapatan perkapita rendah dan menengah. Dimana ISPA juga merupakan salah satu penyebab utama konsultasi atau rawat inap di fasilitas pelayanan kesehatan terutama pada bagian perawatan balita. Tujuan: untuk mengetahui hubungan pengetahuan orangtua dengan tingkat kejadian ISPA pada balita. Metode: Jenis penelitian yang digunakan adalah observasional analitik dengan rancangan cross sectional study. Populasi dalam penelitian ini adalah 20 sampel yang ditentukan dengan tehnik accidental sampling. Hasil: Analisis statistik menggunakan uji statistic pearson correlation. Hasil penetian menunjukkan ada hubungan antara pengetahuan orang tua $(p=0,001)$ dengan kejadian ISPA, di keluarga di Puskesmas Kumbe Kota Bima. Kesimpulan: ada hubungan pengetahuan ibu dengan tingkat kejadian ISPA pada balita.
\end{abstract}

Kata Kunci : Pengetahuan, ISPA, Balita

\section{PARENTS' KNOWLEDGE CORRELATE TO THE INCIDENCE OF UPPER RESPIRATORY TRACTUS INFECTION (URTI) AMONG TODDLERS IN PUSKESMAS KUMBE CITY OF BIMA}

\begin{abstract}
Upper Respiratory Tract Infection (URTI) still become a burden to global health. According to WHO (2007) URTI is the main infectious disease causing morbidity and mortality in the world. Almost 4 million people died because o URTI every year, and $98 \%$ of them were infected in lower respiratory tract. The mortality rate of URTI among infants, toddlers and elderly is very high, especially in countries with middle and low income. URTI is also the most common cause of hospitalization. This study aims to identify the correlation between parents' knowledge and the incidence of URTI among toddlers. This study was an observational analytic with cross sectional design. The samples was 20 parents selected using accidental sampling method. Results showed that using statistic test pearson correlation, there was a correlation between parents' knowledge and the incidence of URTI $(p=0,001)$ among toddlers in Puskesma Kumbe, city of Bima. It can be concluded that parents' knowledge correlate with the incidence of URTI among toddlers.
\end{abstract}

Keywords: knowledge, URTI, toddlers 


\section{PENDAHULUAN}

Sampai saat ini penyakit yang berbasis lingkungan masih merupakan masalah kesehatan di NTB, ini di ketahui dari angka kejadian penyakit ISPA sebagai salah satu penyebab kematian yang cukup tinggi, walaupun beberapa tindakan pencegahan memang efektif. Saat ini ISPA masih menjadi masalah kesehatan dunia.Berdasarkan WHO (2007) ISPA adalah penyebab utama morbiditas dan mortalitas penyakit menular didunia. Hampir 4 juta orang meninggal akibat ISPA setiap tahun 98\%-nya disebabkan oleh infeksi saluran pernapasan bawah. Tingkat mortalitas sangat tinggi pada bayi,balita-balita dan orang lanjut usia, terutama di Negara-negara dengan pendapatan perkapita rendah dan menengah. Dimana ISPA juga merupakan salah satu penyebab utama konsultasi atau rawat inap di fasilitas pelayanan kesehatan terutama pada bagian perawatan balita.

Menurut Saftari (dalam syahrani, 2012) ISPA merupakan msalah kesehatan yang utama di Indonesia karena masih tingginya angka kejadian ISPA terutama pada balita. Prevalensi ISPA di Indonesia sebanyak 25,5\% (rentang: 17,5\% - 41,4\%) dengan 16 propinsi di antaranya mempunyai prevalensi di atas angka nasional dan pneumonia sebanyak $2,1 \%$ (rentang: 0,8\% - 5,6\%) (Riskesdas, 2007). Berdasarkan data yang di peroleh di puskesmas kumbe, kejadian ISPA pada tahun 2019 pada bulan 1 sampai bulan 4 tercatat sebanyak 352 kasus, di samping itu pengetahuan orang tua sangat berpengaruh terhadap insidensi ISPA pada balita. Semakin rendah pendidikan orang tua dengan tingkat kejadian ISPA pada balita akan semakin meningkat, demikian sebaliknya, semakin tinggi pendidikan orang tua tingkat kejadian ISPA yang di derita balita akan ringan.

Namun, bila dilihat dari aktivitas balita yang lebih sering melakukan kegiatan dalam rumah bersama orang tua/anggota keluarga, ISPA yang terjadi pada balita bisa disebabkan oleh lingkungan dalam rumah balita yang tidak memenuhi syarat (Lindarwaty, 2010).Faktorfaktor lingkungan rumah yang dapat mempengaruhi ISPA yaitu faktor lingkungan fisik rumah, faktor perilaku, faktor individu, faktor sosial-ekonomi (Depkes, 2004).Faktor lingkungan fisik rumah salah satunya yaitu ventilasi rumah.Berdasarkan peraturan No. 1077/MENKES/PER/V/2011, setiap rumah wajib memiliki ventilasi minimum 10\% dari luas rumah untuk memenuhi persyaratan rumah sehat. Pada penelitian Lindarwaty (2010) ventilasi rumah yang tidak memenuhi syarat akan menyebabkan ISPA pada balita dengan resiko 3,07 kali lebih besar dibanding dengan ventilasi rumah memenuhi syarat. 
Berdasarkan uraian diatas, penyebab ISPA bukan hanya berasal dari lingkungan luar rumah dengan melihat kadar TSP dimasing-masing lokasi penelitian yang diinginkan. Namun harus diperhatikan apakah ada penyebab dari lingkungan dalam rumah yang meliputi faktor lingkungan fisik rumah, sosial, faktor balita dan faktor perilaku dalam lingkungan kecil yang paling dekat dengan balita setiap hari yang berpotensi menyebabkan balita terkena ISPA.Hal ini supaya program pencegahan yang bersifat lebih luas terhadap penyebab munculnya ISPA.Oleh karena itu, dalam studi ini peneliti ingin mengetahui apakah ada hubungan antara pengaruh lingkungan dalam rumah (faktor lingkungan fisik rumah, sosial, faktor balita, faktor perilaku) terhadap ISPA pada balita di Puskesmas Kel.Kumbe.

\section{METODE}

Desain penelitian menggunakan metode survey analitik dengan pendekatan Cross Sectional yaitu penelitian untuk mempelajari dinamika korelasi antara faktor-faktor resiko dan efek dengan observasi atau pengumpulan data sekaligus pada suatu saat/point time (Notoatmodjo, 2010). Dalam penelitian ini populasinya adalah semua penderita ISPA yang rawat jalan di Puskesmas Kel.Kumbe. dengan responden 352 orang. Tehnik pengambilan sampel yang digunakan adalah "Total Sampling”. Tekhnik pengumpulan data, menggunakan pedoman quisioner.

Pada saat pengumpulan data, peneliti melakukan seleksi terhadap responden untuk memastikan sampel yang memenuhi kriteria inklusi. Langkah - langkah yang dilakukan dalam pengumpulan data yaitu identifikasi terhadap responden berdasarkan hasil quisioner, pemberian nomor pada lembar observasi dan yang telah terisi, memeriksakan kembali kelengkapan hasil observasi yang diperoleh dari status pasien. Setelah dipastikan terisi dengan lengkap, maka kegiatan selanjutnya adalah tahap pengolahan dan analisa data.Pengumpulan data dilakukan dengan menggunakan instrument yang dibuat peneliti dengan mengacu pada sumber kepustakaan. Data yang terkumpul berdasarkan hasil quisioner yang telah dilakukan peneliti pada responden diberi kode sesuai kriteria yang telah ditentukan, di tabulasi, dianalisis secara kuantitatif dan selanjutnya dianalisis dengan uji statistic dengan teknik TTest dengan menggunakan program SPSS.

\section{HASIL PENELITIAN (Times New Roman 11)}

Dalam data khusus ini akan di tampilkan data tentang hubungan pengetahuan orang tua dan kejadian ISPA di Puskesmas Kumbe Kota Bima. 
1. Pengetahuan Orang Tua

Tabel berikut akan menguraikan secara terperinci mengenai pengetahuan orang tua tentang ISPA di Puskesmas Kumbes sebagai berikut:

Tabel 4.7 distribusi frekuensi respon den berdasarkan pengetahuan orang tua di PuskesmasKumbe Kota Bima 22 mei - 4 juni 2019.

\begin{tabular}{lcc}
\hline \multicolumn{1}{c}{ Pengetahuan } & frekuensi & Porsentase \% \\
\hline Kurang & 10 & 50 \\
Cukup & 8 & 40 \\
Baik & 2 & 10 \\
\hline Total & 20 & 100 \\
\hline
\end{tabular}

2. Kejadian ISPA

Tabel berikut akan mengurai secara terperinci mengenai kejadian ISPA di Puskesma Kumbe sebagai berikut:

Tabel 4.8 distribusi frekuensi responden bedasarkan kejadian ISPA diPuskesmasKumbe Kota Bima $22 \mathrm{Mei}$ - 4 Juni 2019.

\begin{tabular}{lcc}
\hline \multicolumn{1}{c}{ Kejadian ISPA } & Frekuensi & Porsentase \% \\
\hline Rendah & 6 & 30 \\
Sedang & 10 & 50 \\
Tinggi & 4 & 20 \\
\hline Total & 20 & 100 \\
\hline
\end{tabular}

3. Analisa Bivariat

Analisis bivariat dimaksudkan untuk melihat hubungan antara variabelvariabel yang di teliti dengan melihat hipotesis yang telah di tetapkan yaitu ada Hubungan Antara pengetahuan orang tua dan kejadian ISPA di Puskesmas Kumbe.

Tabel 4.9 Tabulasi silang hasil pengukuran Pengetahuan Orang Tua Tentang ISPA Dengan Kejadian ISPA Pada Balita Di Puskesmas Kumbe Kota Bima Tahun 2019.

Kejadian ISPA

Jumlah

\begin{tabular}{lcccccccc}
\multirow{2}{*}{ Pengetahuan } & \multicolumn{7}{c}{ Rendah } & \multicolumn{7}{c}{ Sedang } & \multicolumn{2}{c}{ Tinggi } & \\
\cline { 2 - 7 } & $\mathrm{N}$ & $\%$ & $\mathrm{~N}$ & $\%$ & $\mathrm{~N}$ & $\%$ & $\mathrm{n}$ & $\%$ \\
\hline Baik & 6 & 30 & 4 & 20 & 0 & 0 & 10 & 50 \\
Cukup & 0 & 0 & 5 & 25 & 3 & 15 & 8 & 40 \\
Kurang & 0 & 0 & 1 & 5 & 1 & 5 & 2 & 10
\end{tabular}

Uji statistik pearson correlation $\mathrm{p}=0,001 \quad \mathrm{r}=0,668$ 


\section{PEMBAHASAN}

Hasil penelitian menunjukan bahwa kategori pengetahuan ibu kurang yaitu sebanyak 10 responden (50\%), cukup yaitu sebanyak 8 responden (40\%), dan baik yaitu sebanyak 2 responden (10\%). Pembahasan pada penelitian ini akan difokuskan pada pengetahuan orang tua dan kejadian ISPA di Puskesmas Kumbe Kota Bima.

\section{Pengetahuan orang tua}

Berdasarkan hasil penelitian menunjukan bahwa sebagian besar orang tua berpengaruh kurang dan hanya sebagian kecil ibu balita yang memiliki pengetahuan baik tentang ISPA.Hal ini disebabkan karena masih banyak orang tua balita yang pendidikan rendah dan kurangnya mendapatkan informasi mengenai ISPA.

Hasil analisis bivariat dengan menggunakan person correlation menunjukan adanya hubungan yang bermakna antara pengetahuan orang tua dengan kejadian ISPA pada balita. Untuk ibu yang berpengetahuan kurang, balitanya mempunyai resiko terhadap penyakit ISPA dibandingkan dengan yang mempunyai pengetahuan baik. Hasil ini membuktikan hipotesis bahwa ada hubungan antara pengetahuan orang tua dengan kejadian ISPA pada balita

\section{Kejadian ISPA}

Balita sering terpajang oleh beberapa jenis polutan dan virus dengan mudah terutama polutan yang berasal dari dalam rumah karena sekitar $80 \%$ balita menghabiskan waktu di dalam rumah. Selain itu, di tambah lagi dengan daya tahan tubuh yang berbeda setiap balita menyebabkan balita lebih rentang terhadap penyakiy terutama ispa.Keterpajangan balita terhadap bahaya kesehatan lingkungan terjadi di beberapa area yang berbeda yakni di dalam rumah, lingkungan tetangga, dan komunitas di lingkungan yang lebih luas. Terdapat 2 faktor kesehatan pada balita (WHO, 2007) yaitu perumahan dan tempat tinggal (seluruh aspek persediaan dan kualitas perumahan, kepadatan hunian, kondisi rumah yang berbahaya dan tidak aman, kelembapan dan ventilasi yang buruk), dan polusi udara dalam ruangan (misalnya asap dari pemanasan dan proses memasak, perabotan yang mengeluarkan asap, asap rokok di lingkungan sekitar dan zat polutan dari luar lingkungan yang masuk ke dalam ruangan).

\section{Hubungan pengetahuan ibu dengan kejadian ISPA pada balita}

Berdasarkan hasil penelitian menunjukan bahwa sebagian besar orangtua balita berpengaruh kurang dan hanya sebagian kecil orang tua balita yang memiliki pengetahuan baik tantang ISPA.Hal ini disebabkan karena masih banyaknya orang tua balita yang 
pendidikannya rendah dan kurangnya mendapatkan informasi mengenai ISPA. Hasil analisis bivariat dengan menggunakan person correlation menunjukan adanya hubungan yang bermakna antara pengetahuan orang tua dengan kejadian ISPA pada balita. Untuk orang tua yang berpengetahuan kurang, balitanya mempunyai resiko terhadap penyakit ISPA 4,33 kali dibandingkan dengan yang mempunyai pengetahuan baik. Hasil ini membuktikan hipotesis bahwa ada hubungan pengetahuan orang tua dengan kejadian ISPA pada balita.

Menurut sutrisna, B (1993), ditemukan adanya hubungan antara pengetahuan orang tua tentang mengatasi dalam kejadian ISPA. Tingkat pengetahuan sangat penting dimiliki oleh seseorang, karena tingkat pengetahuan merupakan suatu wawasan yang akan menyebabkan perubahan seseorang dalam bersikap dan bertindak dalam mengatasi permasalahan yang timbul dalam kehidupan.

Hasil penelitian ini sejalan dengan penelitian ariyanto, Y (2008) bahwa dampak pengetahuan terhadap kejadian ISPA pada balita cukup besar, yang berarti jika pengetahuan orang tua tentang faktor resiko ISPA ditingkatkan maka kejadian ISPA pada balita akan berkurang. Begitupula dengan hasil penelitian Nurjazuli, dkk,(2009), menyimpulkan adanya hubungan antara pengetahuan orang tua dengan kejadian ISPA pada balita.

\section{KESIMPULAN}

Berdasarkan hasil penelitian dan pembahasan yang telah dijelaskan pada bab-bab sebelumnya , maka dapat ditarik kesimpulan sebagai berikut:

1. Masih tingginya angka kejadian ISPA pada balita di Puskesmas Kumbe Kota Bima.

2. Pengetahuan orang tua tentang penyakit ISPA masih rendah. Masih banyak orang tua balita yang tidak mengetahui faktor-faktor resiko dan bahaya dari penyakit ISPA, kebanyakan ibu menyatakan ISPA merupakan suatu penyakit biasa yang bisa sembuh dengan sendirinya.

3. Balita yang mendapatkan ASI eksklusif memiliki resiko lebih kecil untuk terserang ISPA

4. Keberadaan perokok dalam rumah terbukti sangat mempengaruhi kesehatan balita, terutama untuk terserang penyakit ISPA $(\mathrm{OR}=40,5)$, begitupula dengan kepemilikan ventilasi dalam rumah dan kepadatan hunian yang tidak memenuhi syarat.

\section{Saran yang dapat kami berikan}

1. Bagi Puskesmas Kumbe sebagai instalasi pelayanan kesehatan diharapkan semua petugas kesehatan di Puskesmas Kumbe dapat terus memberikan penyuluhan dan informasi lebih 
lanjut terhadap masyarakat terutama orang tua tentang perawatan ISPA pada balita dengan baik dan benar

2. Bagi institusi pendidikan skripsi ini dapat menjadi informasi tambahan bagi pembaca dan institusi sebaiknya lebih banyak lagi menyediakan buku bacaan

3. Bagi peneliti lain diharapkan dapat mengembangkan lebih lanjut pada penelitian sejenis, mengenai pemberian ASI, status giji, sosial ekonomi, dan faktor lingkungan seperti pencemaran udara dalam rumah sehingga diperoleh hasil penelitian yang lebih variatif.

\section{DAFTAR PUSTAKA}

Achmadi, Umar Fahmi, 2008. Manajemen Penyakit Berbasis Wilayah. Universitas Indonesia Press. Jakarta

Anonim, 2007.Profil Kesehatan di Indonesia. Depkes RI, Jakarta.

Aprinda D.S, Soedjajadi K, 2007. Hubungan Tingkat Kesehatan Rumah Dengan Kejadian Infeksi Saluran Pernafasan Akut. Jurnal Kesehatan Lingkungan, VOL. 3, NO.2, JANUARI 2007: 139-150.

Avrianto, Fanji, 2011. Analisis Kadar Partulate Mattrer 10 (PM10) di Udara dan Keluhan Gangguan Pernafasan Pada Masyarakat yang Tinggal di Sepanjang Jalan Raya Kelurahan Lalang Kecamatan Sunggal Medan.Skripsi Fakultas Kesehatan Masyarakat Universitas Sumatra Medan.

Badan Pusat Statistik, 2003. Statistik Lingkungan Hidup Indonesia 2002.PT. Relindo Jaya, Jakarta.

BPLH, 2012.Pengukuran Kadar TSP di Wilayah Kota Tangerang Selatan.Tangsel.

Citra, Putri, 2012. Hubungan Lingkungan Dalam Rumah Dengan Kejadian ISPA Pada Balita Di Wilayah Kerja Puskesmas Atang Jungket Kecamatan Bies Kabupaten Aceh Tengah Tahun 2012.Skripsi. FKM UI. Depok.

Depkes RI, 2000. Pedoman Program Pemberantasan Penyakit Infeksi Saluran Pernafasan Akut.Direktorat PPM \& PL. Jakarta.

Depkes RI, 2004. Pedoman Pemberantasan Penyakit Infeksi Saluran Pernapasan Akut Untuk Penanggulangan Pneumonia pada Balita. Jakarta.

Depkes RI, 2005. Rencana Kerja Jangka Menengah Nasional Penanggulangan Pneumonia Pada Balita 2005-2009.

Depkes RI 2006.Pedoman Pengendalian Penyakit Infeksi Saluran Pernapasan Akut Untuk Penanggulangan Pneumonia Pada Balita. Jakarta. 
Depkes RI, 2008. Laporan Hasil Riset Kesehatan Dasar. Riskesdes Indonesia tahun 2007.

Gertudis T, 2010. Hubungan Antara Partikulat (PM10) Udara Rumah Tinggal Dengan Kejadian ISPA Pada Balita Di Sekitar Pabrik Semen PT Indocement, Citeurep, 2011. Tesis Fakultas Kesehatan Masyarakat UI. Depok.

Irianto, 2006.Hubungan Faktor Lingkungan Rumah dan Karakteristik Balita Dengan Kejadian Penyakit ISPA Pada Balita Di Wilayah Kecamatan Lemahwungkuk Kota Cirebon.Program Pasca Sarjana FKM UI. Depok.

Lindawaty, 2010.Partikulat (PM10) Udara Rumah Tinggal Mempengaruhi Kejadian ISPA Pada Balita (Penelitian Di Kecamatan Mampang Prapatan, Jakarta Selatan Tahun 20092010). Tesis Fakultas Kesehatan Masyarakat UI. Depok.

Maramis, Anjanata, Paramitha, dkk.(2013). Hubungan Tingkat Pendidikan Dan Pengetahuan Ibu Tentang ISPA Dengan 